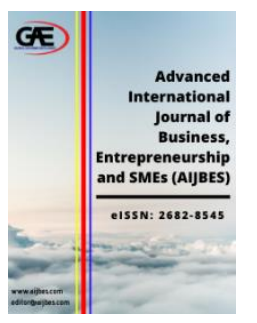

\author{
ADVANCED INTERNATIONAL JOURNAL OF \\ BUSINESS, ENTREPRENEURSHIP AND SMES \\ (AIJBES) \\ WWW.aijbes.com
}

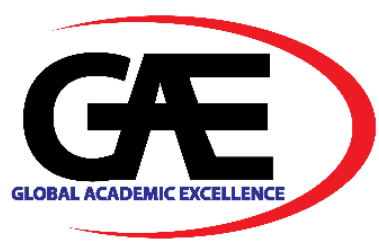

\title{
COMPETING MARKET LEADER IN INDONESIA'S CONSTRUCTION INDUSTRY
}

\author{
Erika Yuono Putri ${ }^{1 *}$ \\ 1 School of Business and Management, Bandung Institute of Technology, Indonesia \\ Email: erika_yuono@sbm-itb.ac.id \\ * $\quad$ Corresponding Author
}

\section{Article Info:}

\section{Article history:}

Received date: 20.05 .2021

Revised date: 25.05 .2021

Accepted date: 02.06 .2021

Published date: 15.06.2021

\section{To cite this document:}

Putri, E. Y. (2021). Competing Market Leader In Indonesia's Construction Industry. Advanced International Journal of Business, Entrepreneurship and SMEs, 3 (8), 75 85.

DOI: $10.35631 /$ AIJBES.38005.

This work is licensed under $\mathrm{CC}$ BY 4.0 (a)

\begin{abstract}
:
The growth of the construction industry in Indonesia is constantly bearing straight to its economic growth and contributes by more than $10 \%$ to the country's gross domestic product in the period 2015-2020. The construction market share in Indonesia is dominated by large contractors who control $85 \%$ of the total projects even though they are only $0.96 \%$ of the total population, while the smaller contractors only control the remaining $15 \%$. Smaller companies only select a project based on their experience and colleagues' recommendations. It is getting worse because the decision-makers never consider any method to assist the decision-making process as they do not have sufficient knowledge, then they should face some losses which cost big amounts of money compared to their companies' size The use of AHP on this research will help the smaller contractors to take better decision making yet minimizing their chance of failure and risk. The objectives of this research are to determine the factors that significantly influence project selection in the construction industry and to provide recommendations of the project selection for the construction industry. This research aims to support the smaller contractors to utilize their chance in project selection in order to compete with the big companies. The research will use focus group discussion between the directors of several construction companies as they have full responsibility in the company's decision-making process and are used to going straight to the field while also doing the bidding.
\end{abstract}

Keywords:

Construction Industry, Analytical Hierarchy Process, Project Selection

\section{Introduction}

The growth of the construction industry in Indonesia is constantly bearing straight to its economic growth, while at the same time also contributing by more than $10 \%$ to the country's gross domestic product in the period 2015-2020. In the third quarter of 2020 along with the 
Volume 3 Issue 8 (June 2021) PP. 75-85

DOI 10.35631/AIJBES.38005

pandemic occurrence, the construction sector still positively contributed to the country's Gross Domestic Product at the amount of 10.6. Therefore, it is predicted that in 2021 the construction industry will also give a positive contribution by $10.7 \%$ (Kompas, 2020). According to those facts and predictions, it can be concluded that the construction industry as a whole holds a strong influence on the country's economic condition.

Based on data provided by BPS (2020), construction market share in Indonesia is dominated by large contractors who control $85 \%$ of the total projects even though they are only $0.96 \%$ of the total population of contractors in Indonesia. While the smaller contractors number more than 120,000 only control the remaining $15 \%$ of the total projects (INews.id, 2020). These facts show that there is an imbalance in the construction industry which causes injustice for the smaller contractors. The smaller contractors have limited rights to develop their ability and enrich their knowledge as the chances are dominated by the big companies.

Project selection is a crucial decision for a company as it will affect the overall output of a company and the long-term business stability. The project selection in the construction industry can be categorized as the most important and challenging decision to make as the construction industry is considered one of the riskiest industries. In selecting projects, the decision maker often makes wrong decisions and results in failure to achieve quality and budget goals while unable to fulfill the time limitation (Parvaneh \& El-Sayegh, 2016). Construction projects characteristics are complex, where they have a high amount of uncertainties and degree of subjectivity that vary between projects, therefore choosing a suitable project to generate good returns and minimum risk is inherently difficult (Nandi et al., 2011).

Project selection is a decision making process which is influenced by some conflicting objectives. In a project based organization, the availability of resources and project selection methods are becoming the most important issue, considering that the organizations may have limited resources. Thus, they need to prioritize the least riskiest project (Chatterjee et al., 2018). The contradiction between those two interests often causes confusion for the decision maker to select the best project to be handled, while at the same time they should consider the competitive environment in order to survive in this industry.

Unlike the bigger companies, the decision makers in smaller companies only select a project based on their experience and colleagues' recommendation without considering other important aspects. Whereas, there are various aspects that need to be considered including company capability and resource, risk level and also the feasibility of the project to generate benefits for the company. The current condition is getting worse because the decision makers never consider any method to assist the decision-making process as they do not have sufficient knowledge to develop such an idea or even implement the idea to ease their job yet gaining a bigger profit and minimizing risk they will be beared in the future.

In the context of building contractors, several projects may be available at the same time which require the decision maker to do the project bidding. Thus, the decision maker only has a limited time to think about the overall aspects that they need to consider. Even though the decision-making process itself needs quite a long time. As the insufficient knowledge that they have, longer time would not generate any better result without using the appropriate method. As an impact of the insufficient knowledge, they failed to choose a suitable project to be handled and in the end they should face some losses which cost big amounts of money 
Volume 3 Issue 8 (June 2021) PP. 75-85 DOI 10.35631/AIJBES.38005

compared to their companies' size. Therefore, the researcher wants to use Analytical Hierarchy Process to assist the decision makers to select a suitable project for their companies.

Based on the decision maker experience, most of the projects were selected based on its ability to generate profit. Therefore, it can be concluded that quantitative factors were dominating the project election process although it did not cover the overall and detailed quantitative factor components. While based on a study proposed by Parvaneh \& El-Sayegh (2016), quantitative factors are insufficient to assess the result of the project selection yet the method should cover both qualitative and quantitative factors in order to provide the best solution. The qualitative factors mentioned include organizational culture, experience, priorities of the projects, location, political and economic condition.

Considering the weakness of using decision's maker intuition and experience, the researcher intends to use the AHP method. Analytical Hierarchy Process (AHP) is an approach conducted by structuring multiple criteria into a hierarchy, assessing the relative importance of these criteria, comparing alternatives for each criteria and determining overall ranking of the alternatives (Nandi et al., 2011). Sharma \& Kumar (2018) proposed that AHP can help the researcher to access both tangible and intangible aspects in a more systematic way, AHP has been successfully applied to several problems and has a high level of acceptances.

As it is known that the construction industry in Indonesia is significantly developing, the use of AHP will help the decision maker to select an appropriate project as it will capture both subjective and objective points of views, thus will reduce biases in the project selection process. AHP also assists the researcher to deal with complex decision making by providing proven results by analyzing the weight of each criteria and sub-criteria and finally accelerate the decision making process (Nandi et al., 2011). As AHP will manifest the decision maker's experience, intuition, real condition and various project information into calculated numbers, this will make significant progress for the smaller construction companies and consequently will make them able to compete with the larger companies which currently dominate the market.

Although there is a limited research which studied about the project selection in the construction industry using AHP method, this method has been successfully applied to solve several problems in the construction industry context such as in the study propose by Wang et al. (2017) which was using the combination of AHP and GRA methods to select supplier in order to support their supply chain. Study proposed by (Hoseinpoor \& Alborzi, 2019) also used the combination of AHP and DEA to support the selection of contractors participating in tenders. Besides, AHP also successfully used beyond construction industry context which were project manager selection for Indian business environment (Sharma \& Kumar, 2018), and project selection in the case of solar energy plant (Çoban, 2020).

The objectives of this research is to determine the factors that significantly influence project selection in the construction industry and to provide recommendations of the project selection for the construction industry. This research aims to support the smaller contractors to utilize their chance in project selection in order to compete with the big companies. The research is conducted in Commanditaire Vennootschap (CV) of building contractors which are sole proprietorship companies in the construction industry that is located in East Java. The assessment of the project selection is only limited to expert judgement. 


\section{Literature Review}

\section{Construction Industry}

Construction industry contributes to both the country's public and private infrastructure in the form of services, commerce, utilities and other industries while it is also opening up the field of work directly (Wibowo, 2004). In Indonesia, construction sector growth is linear with the country's economic growth (PEFINDO, 2020). Nevertheless, based on data provided by BPS, (2020), construction market 'share in Indonesia is dominated by large contractors who control $85 \%$ of the total projects even though they are only $0.96 \%$ of the total population of contractors in Indonesia. This fact is showing that the smaller contractors are unable to compete with the bigger contractors. As stated by Nandi et al. (2011), the failure of contractors may occur as the effect of the lack of systematic risk assessment and rarely do they quantify the uncertainty of the project.

\section{Project Selection In Construction Industry}

Project selection is a crucial matter that organizations have to deal with as it is required to guarantee business survival (Moselhi \& Deb, 1993). Project portfolio selections can be defined as periodic activities to choose a project which meets the company's stated objectives and without exceeding company resources within several projects available (Archer \& Ghasemzadeh, 1999). The complexities of choosing a project happens as the impact of company's objectives and priorities to the various attributes to consider such as tangible and intangible benefits, risk tolerance and resource availability (Enea \& Piazza, 2004).The use AHP in Indonesian construction industry is necessary in order to minimize risk and able to quantify the worth of each project.

\section{Analytical Hierarchy Process}

Analytical Hierarchy process might help the decision maker In a company to produce a better decision within several alternatives (Hines, 1998). This approach ensures that the decision was made rationally. AHP helps in arranging unstructured problems into decision hierarchy which lead to repeated processes to tackle responses that might be inconsistent (Nandi et al., 2011). This approach developed by using pairwise comparisons of individual judgement which usually ask for experts' involvement to compare the alternatives (Omotayo et al., 2020). The absolute scale was developed by Saaty which scaled from 1-9 provides references of valuing the importance of each criteria (Saaty, 2003). Based on a study proposed by Hafeez et al. (2002), AHP can provide a structured framework to assess the competency of a company. Liang (2003) shows that AHP is the simplest approach compared to others in their case of project termination.

Nydick \& Hill (1992) also use AHP to assist in the supplier selection process. Based on a study proposed by Kendrick \& Saaty (2007), AHP was helped to improve the business process of organizations based on the organization's objectives. Dey (2004) uses AHP to make a support system in making a decision for project selection and evaluation. Marzouk \& Moselhi ( 2003) show a decision support model for construction bidding, which helps the contractors to estimate the markups and assist the clients to make proposal evaluations. Based on a study proposed by Al-Harbi (2001), in order to make a list of alternative contractors and select the favorable contractor, AHP is also used as decision making tools. Alhazmi \& McCaffer (2000) also stated that the use of AHP method might reduce the cost of construction projects by $5 \%$. 


\section{Analytical Hierarchy Process}

The method that will be used in this research is Analytical Hierarchy Process (AHP). This method is chosen because it is an appropriate method to select the alternative solution in the decision making process according to the expert's judgment towards the given criteria. Therefore, AHP method will be used by the researcher to assist the selection process of project selections for building contractors.

\section{Pairwise Comparison}

Pairwise comparison is used to determine the value of each criteria compared to other criteria and also applies for the sub-criteria. This step will be done using Focus Group Discussion between experts. The scale that will be used for the pairwise comparison is shown in the table 1.

Table 1: Saaty Scale

\begin{tabular}{|c|c|c|}
\hline $\begin{array}{c}\text { Intensity of } \\
\text { importance on an } \\
\text { absolute scale } \\
\end{array}$ & Definition & Explanation \\
\hline 1 & Equal importance & $\begin{array}{l}\text { Two activities contribute } \\
\text { equally to the objective }\end{array}$ \\
\hline 3 & $\begin{array}{l}\text { Moderate importance of one } \\
\text { over another }\end{array}$ & $\begin{array}{l}\text { Experience and judgement } \\
\text { strongly favour one activity } \\
\text { over another }\end{array}$ \\
\hline 5 & $\begin{array}{l}\text { Essential or strong } \\
\text { importance }\end{array}$ & $\begin{array}{l}\text { Experience and judgement } \\
\text { strongly favour one activity } \\
\text { over another }\end{array}$ \\
\hline 7 & Very strong importance & $\begin{array}{l}\text { An activity is strongly } \\
\text { favoured and its dominance } \\
\text { demonstrated in practice }\end{array}$ \\
\hline 9 & Extreme importance & $\begin{array}{l}\text { The evidence favouring one } \\
\text { activity over another is of the } \\
\text { highest possible order of } \\
\text { affirmation }\end{array}$ \\
\hline $2,4,6,8$ & $\begin{array}{l}\text { Intermediate values between } \\
\text { the two adjacent judgements }\end{array}$ & When compromise is needed \\
\hline
\end{tabular}

Source: Saaty (2003)

\section{Criteria Weights Calculation}

The calculation of criteria weights will be done by using the data that is obtained from the pairwise comparison in the Focus Group Discussion. After the values of pairwise comparison have been obtained, the weight of the criteria will be calculated using Super Decision Software. 
Volume 3 Issue 8 (June 2021) PP. 75-85 DOI 10.35631/AIJBES.38005

Cabrera et al. (2018) expressed the equation of the pairwise comparison and also calculation of the eigen value as follows:

$$
\begin{gathered}
A=\left\{\begin{array}{ccc}
1 & a_{12} \ldots & a_{1 n} \\
a_{21} & 1 \ldots & a_{2 n} \\
a_{n 1} & a_{n 2} \ldots & 1
\end{array}\right\} \\
a_{i j}=\frac{\text { weight of attribute } i}{\text { weight of attribute } j}
\end{gathered}
$$

\section{Sub-criteria Weights Calculation}

The calculation of sub-criteria weights will be done by using the data that is obtained from the pairwise comparison in the Focus Group Discussion. After the values of pairwise comparison have been obtained, the weight of the sub-criteria will be calculated using Super Decision Software. Afterwards, the global weights of each sub-criteria can be calculated by multiplying the local weights of criteria and the local weight of each sub-criteria. The equation and eigenvalue calculation are similar to the criteria weight calculation.

\section{Checking the Consistency}

Based on the data obtained, the assessment of its consistency should be done to test whether the expert's judgments for each component is consistent. The consistency calculation will be done using Super Decision Software. Saaty (2003) expressed the calculation of consistency ratio by using the formula as follows:

$$
\begin{aligned}
& \mathrm{CI}=(\text { Lambda } \max -n) /(n-1) \\
& \mathrm{CR}=\mathrm{CI} / \mathrm{RI}
\end{aligned}
$$

Based on the study proposed by Hines (1998) the output of the consistency should be less than 0.1 for the assessment to be consistent, otherwise the components should be reassessed.

\section{Scoring the Alternatives}

Besides assessing the criteria and sub-criteria, the experts should assess the alternatives capability towards each sub-criteria. The alternatives scoring will also be done using Super Decision Software.

\section{Ranking the Alternatives}

In order to select the best alternative, the calculation to rank the alternatives should be done by multiplying the global weights of each sub-criteria with the score of each alternative. As the overall score of the alternatives are calculated, the ranking of the alternatives can be determined. Afterwards, the alternative with the highest score will be selected as the best project selection method for building contractor companies. 


\section{Data Collection}

In doing the research, the researcher collects the primary data from the experts in the construction industry. The experts will consist of the directors of several building contractor companies. As the directors of the companies have full responsibility in the company's decision making process and are used to going straight to the field while also doing the bidding, they will be the most suitable people to be chosen as the experts. The researcher will do a Focus Discussion Group between the experts to assist their judgment towards the criteria and subcriteria based on their professional knowledge.

\section{Discussion and Analysis}

Before conducting AHP, it is required to define the criteria and sub-criteria where in this context is the project selection criteria and sub-criteria. The list of the criteria and sub-criteria as stated in the Table 2 are adopted from the previous study by Nandi et al. (2011) that was conducted in India with the similar case of project selection in the construction industry sector. The data provided by the study consist of 11 criteria and breakdown into several sub-criteria. Further, the researcher also considered the experts' point of view by doing an in- depth interview regarding the criteria and sub-criteria provided previously. Considering the result of the interview process, the researcher adds some criteria (e.g. project value, size and complexity) and eliminates some sub-criteria which is not relevant with the current field condition. The addition and the elimination process are needed as the period of time, the paper is based on the study in India and was studied 10 years ago. Other than that, the paper also studies about the bigger building construction context therefore, the consideration of developing some subcriteria will also be different. Experts consist of several directors of the building contractors which have the full authority to make any of the company decisions including the bidding process.

Table 2: The Criteria and Sub-Criteria

\begin{tabular}{|c|c|}
\hline Criteria & Sub-criteria \\
\hline \multirow[t]{3}{*}{ Financial } & Profitability \\
\hline & Project value \\
\hline & Capital support \\
\hline \multirow[t]{3}{*}{ Technical } & Previous experience with executing similar type of work \\
\hline & Access to required equipment \\
\hline & Size and Complexity \\
\hline \multirow[t]{4}{*}{ Resources } & Availability of sufficient equipments \\
\hline & Availability of in house technical expert personnel \\
\hline & Availability of adequate human resources at the project \\
\hline & $\begin{array}{l}\text { location } \\
\text { Availability of adeoule materials at the proiect location }\end{array}$ \\
\hline \multirow[t]{3}{*}{ Risk } & Unstable weather \\
\hline & Government clearance \\
\hline & Land acquisition issues \\
\hline \multirow[t]{5}{*}{ Contract Clause } & Provisions for time extension \\
\hline & Construction warranty period \\
\hline & Bank guarantee \\
\hline & Payments terms \\
\hline & Time frame of completion \\
\hline
\end{tabular}


Volume 3 Issue 8 (June 2021) PP. 75-85 DOI 10.35631/AIJBES.38005

\begin{tabular}{ll}
\hline Client & $\begin{array}{l}\text { Financial strength of client for project execution cost } \\
\text { Quality of relationship/past experience with the client } \\
\text { Hassle free relationship with the client }\end{array}$ \\
\hline Location factors & \begin{tabular}{l} 
Availability of public infrastructure \\
Availability of energy supply and water \\
Mobilisation Cost \\
Having ongoing projects in the vicinity (equipment or \\
manpower can be mobilized easily if needed) \\
Eco-environmental sensitivity of the project location (change \\
of environmental conditions, disease transfer) \\
factors \\
$\begin{array}{l}\text { Impacts to public health } \\
\text { Waste assessment (waste generation across project life cycle, } \\
\text { waste management plan and methods, waste disposal } \\
\text { technologies) } \\
\text { Ecological impacts of the project (ecological risks and } \\
\text { benefits associated with the proposed project) }\end{array}$ \\
\hline Stability of the government and political scenario \\
Past history of violence and riots in the recent past
\end{tabular} \\
\hline Prestige value \\
Prequalification for future similar kind of projects
\end{tabular}

Source: Nandi et al. (2011)

After the data needed are collected, researchers will analyze the data using Analytical Hierarchy Process using Super Decision Software. By using this method, the researcher can assess the criteria and sub-criteria which are suitable for the project selection process in the construction industry based on the literature review using expert judgements which are the directors of several building contractors. When the weight of criteria and sub-criteria are determined, each project alternatives can be assessed according to each of the sub-criteria that will generate the score for each project alternatives. Further, the researcher can rank the score of each criteria and finally select the best alternative as the result of the project selection process.

Table 3 below will describe the detail of each alternative in choosing a project for building contractors. In this research, the projects are hypothetical based on the most frequent project that the contractors mostly have.

Table 3: Alternatives

\begin{tabular}{lllll}
\hline \multicolumn{1}{c}{ Description } & \multicolumn{1}{c}{ A } & \multicolumn{1}{c}{ B } & \multicolumn{1}{c}{ C } & \multicolumn{1}{c}{ D } \\
\hline Project type & Building & Public Facilities & Building & Public Facilities \\
\hline Project specific & Private Housing & Water Tunnel & School Building & Road Project \\
\hline Location & $\begin{array}{l}\text { Local prime } \\
\text { area }\end{array}$ & Rural area & $\begin{array}{l}\text { Local suburban } \\
\text { area }\end{array}$ & $\begin{array}{l}\text { Local suburban } \\
\text { area }\end{array}$ \\
\hline Project owner & Private & Government & Government & Government \\
\hline
\end{tabular}


Volume 3 Issue 8 (June 2021) PP. 75-85 DOI 10.35631/AIJBES.38005

\begin{tabular}{lllll}
\hline $\begin{array}{l}\text { Project size } \\
\text { (capital } \\
\text { investment) }\end{array}$ & Large & Medium & Medium & Medium \\
\hline $\begin{array}{l}\text { Project } \\
\text { duration }\end{array}$ & 12 months & 3 months & 3 months & 3 months \\
\hline $\begin{array}{l}\text { Projected } \\
\text { profit } \\
\text { point scale) }\end{array}$ & 5 & 7 & 6 & 8 \\
\begin{tabular}{l} 
Project risk \\
\hline
\end{tabular} & Low & Medium & Medium & High \\
\hline
\end{tabular}

\section{Establish the AHP Model}

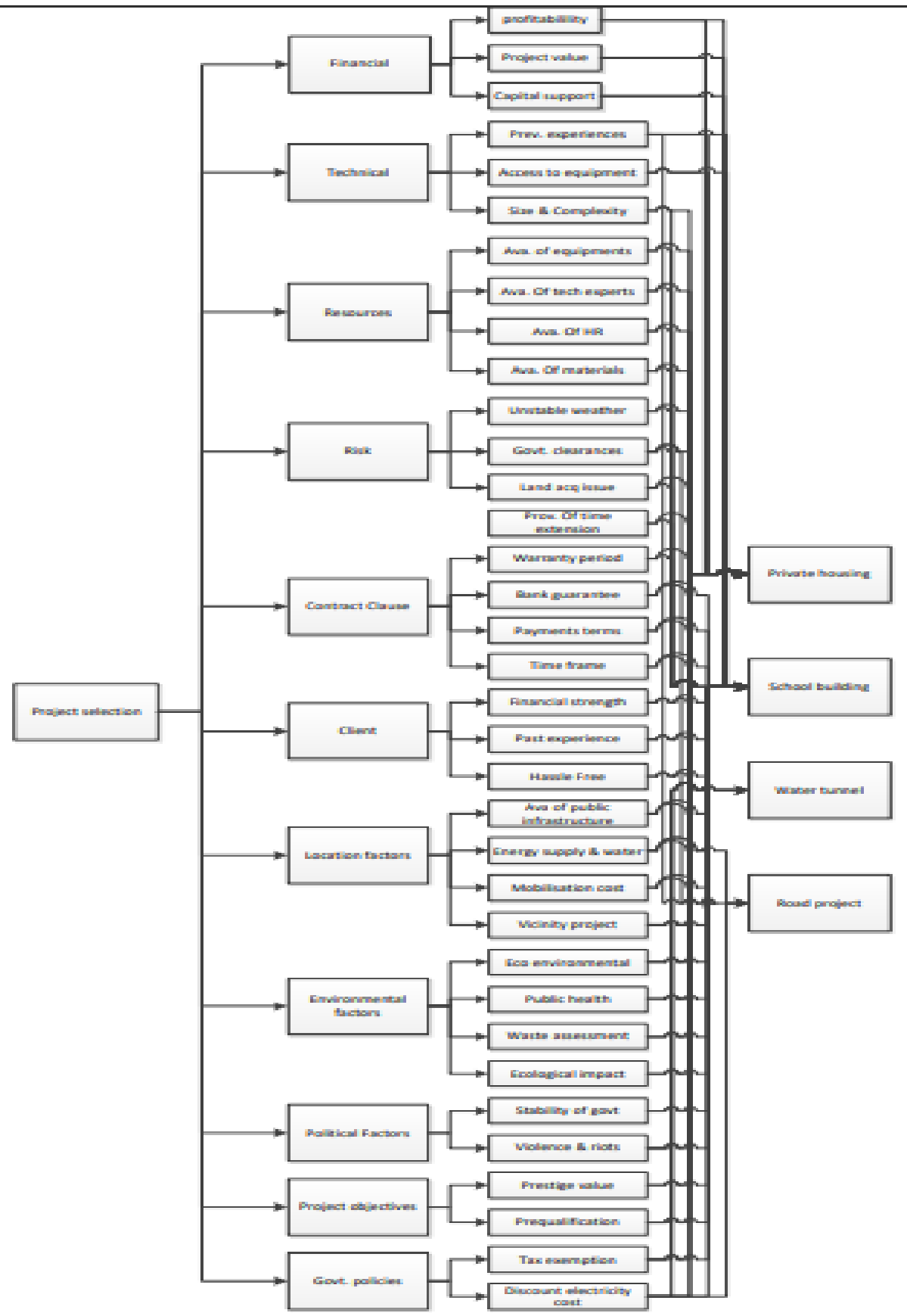




\section{Conclusions}

This research shows factors that significantly influence project selection in the construction industry in order to provide recommendation of the project selection for the construction industry. This research in the proposed conceptual model will be tested in the future study. The conceptual model used will be Analytical Hierarchy Process assessed by experts focus group discussion. The use of AHP will help the decision maker to select an appropriate project as it will capture both subjective and objective points of views, thus reducing biases in the project selection process. As AHP will manifest the decision maker's experience, intuition, real condition and various project information into calculated numbers, this will make significant progress for the smaller construction companies and consequently will make them able to compete with the larger companies which currently dominate the market.

\section{References}

Al-Harbi, K. M. A. S. (2001). Application of the AHP in project management. International Journal of Project Management. https://doi.org/10.1016/S0263-7863(99)00038-1

Alhazmi, T., \& McCaffer, R. (2000). Project Procurement System Selection Model. Journal of Construction Engineering and Management. https://doi.org/10.1061/(asce)07339364(2000)126:3(176)

Archer, N. P., \& Ghasemzadeh, F. (1999). An integrated framework for project portfolio selection. International Journal of Project Management. https://doi.org/10.1016/S02637863(98)00032-5

BPS. (2020). Banyaknya Perusahaan Konstruksi 2018-2020. https://www.bps.go.id/indicator/4/216/1/banyaknya-perusahaan-konstruksi.html

Cabrera, D., Cabrera, L., Powers, E., Solin, J., \& Kushner, J. (2018). Applying systems thinking models of organizational design and change in community operational research. European Journal of Operational Research. https://doi.org/10.1016/j.ejor.2017.11.006

Chatterjee, K., Hossain, S. A., \& Kar, S. (2018). Prioritization of project proposals in portfolio management using fuzzy AHP. OPSEARCH. https://doi.org/10.1007/s12597-018$0331-3$

Çoban, V. (2020). Solar energy plant project selection with AHP decision-making method based on hesitant fuzzy linguistic evaluation. Complex \& Intelligent Systems. https://doi.org/10.1007/s40747-020-00152-5

Dey, P. K. (2004). Analytic hierarchy process helps evaluate project in Indian oil pipelines industry. International Journal of Operations and Production Management, 24(5-6), 588-604. https://doi.org/10.1108/01443570410538122

Enea, M., \& Piazza, T. (2004). Project selection by constrained fuzzy AHP. Fuzzy Optimization and Decision Making. https://doi.org/10.1023/B:FODM.0000013071.63614.3d

Hafeez, K., Zhang, Y. B., \& Malak, N. (2002). Determining key capabilities of a firm using analytic hierarchy process. International Journal of Production Economics. https://doi.org/10.1016/S0925-5273(01)00141-4

Hines, P. (1998). Review of: "Gemba Kaizen: a common sense, low-cost approach to management”Masaaki Imai McGraw-Hill, New York ISBN 0-07-031446-2 (hardback) $354 \mathrm{pp}$. International Journal of Logistics Research and Applications. https://doi.org/10.1080/13675569808962041 
Volume 3 Issue 8 (June 2021) PP. 75-85 DOI 10.35631/AIJBES.38005

Hoseinpoor, A., \& Alborzi, M. (2019). The combination of DEA and AHP approach in the selection of contractors participating in tenders. HOLOS. https://doi.org/10.15628/holos.2019.6065

INews.id. (2020). Timpang, 1 Persen Kontraktor Besar Kuasai 85 Persen Proyek di Indonesia. https://www.inews.id/finance/bisnis/timpang-1-persen-kontraktor-besar-kuasai-85persen-proyek-di-indonesia

Kendrick, J. D., \& Saaty, D. (2007). Use Analytic Hierarchy Process for Project Selection. ASQ Six Sigma Forum 22--29. http://dschoenherr.fatcow.com/sitebuildercontent/sitebuilderfiles/analytic_hierarchy_p rocess.pdf

Kompas. (2020). Tahun Depan, Sektor Konstruksi Diperkirakan Tumbuh hingga 6,7 Persen. https://properti.kompas.com/read/2020/12/30/130000821/tahun-depan-sektorkonstruksi-diperkirakan-tumbuh-hingga-67-persen

Liang, W. Y. (2003). The analytic hierarchy process in project evaluation: An R\&D case study in Taiwan. Benchmarking. https://doi.org/10.1108/14635770310495492

Marzouk, M., \& Moselhi, O. (2003). A decision support tool for construction bidding. Construction Innovation. https://doi.org/10.1108/14714170310814882

Moselhi, O., \& Deb, B. (1993). Project selection considering risk. Construction Management and Economics. https://doi.org/10.1080/01446199300000063

Nandi, S., Paul, S., \& Phadtare, M. (2011). An AHP-based construction project selection method. Decision.

Nydick, R. L., \& Hill, R. P. (1992). Using the Analytic Hierarchy Process to Structure the Supplier Selection Procedure. International Journal of Purchasing and Materials Management. https://doi.org/10.1111/j.1745-493x.1992.tb00561.x

Omotayo, T., Awuzie, B., Egbelakin, T., \& Obi, L. (2020). AHP-Systems Thinking Analyses for Kaizen Costing. Buildings, 10(12), 230.

Parvaneh, F., \& El-Sayegh, S. M. (2016). Project selection using the combined approach of AHP and LP. Journal of Financial Management of Property and Construction, 21(1), 39-53. https://doi.org/10.1108/JFMPC-09-2015-0034

PEFINDO. (2020). CONSTRUCTION INDUSTRY (Issue August).

Saaty, T. 1. (2003). Saaty T.L. (2003), The Analytic Hierarchy Process (AHP) for Decision Making and the Analytic Network Process (ANP) for Decision Making with Dependence and Feedback. Creative Decisions Foundation.

Sharma, K. K., \& Kumar, A. (2018). Facilitating quality project manager selection for Indian business environment using analytical hierarchy process. International Journal of Quality and Reliability Management. https://doi.org/10.1108/IJQRM-10-2016-0175

Wang, T. K., Zhang, Q., Chong, H. Y., \& Wang, X. (2017). Integrated supplier selection framework in a resilient construction supply chain: An approach via analytic hierarchy process (AHP) and grey relational analysis (GRA). Sustainability (Switzerland). https://doi.org/10.3390/su9020289

Wibowo, A. (2004). the Contribution of the Construction Industry To the Economy of Indonesia: a Systemic Approach. International Symposium in Developing Economies: Commonalities among Diversities. 